\title{
Cholinergic Regulation of Brain-derived Neurotrophic Factor (BDNF) and Nerve Growth Factor (NGF) but Not Neurotrophin-3 (NT-3) mRNA Levels in the Developing Rat Hippocampus
}

\author{
Maria da Penha Berzaghi, ${ }^{1}$ Jonathan Cooper, ${ }^{2}$ Eero Castrén, ${ }^{1}$ Francisco Zafra, ${ }^{1,3}$ Michael Sofroniew, ${ }^{2}$ Hans \\ Thoenen, ${ }^{1}$ and Dan Lindholm ${ }^{1}$ \\ ${ }^{1}$ Department of Neurochemistry, Max Planck Institute for Psychiatry, D-8033 Planegg Martinsried, Germany, ${ }^{2}$ Department \\ of Anatomy, University of Cambridge, Cambridge, CB2 3DY, England, and ${ }^{3}$ Centro de Biologia Molecular, Universidad \\ Autonoma de Madrid, E-28049 Madrid, Spain
}

In previous experiments it has been demonstrated that the synthesis of BDNF (brain-derived neurotrophic factor) and NGF in neurons of the hippocampus is regulated by neuronal activity. The glutamate system is predominantly responsible for upregulation and the GABAergic system for downregulation both in vitro and in vivo (Zafra et al., 1990, 1991). The aim of the present study is to examine the extent to which the cholinergic system is also involved in the regulation of NGF and BDNF mRNA and whether the regulatory contribution of the cholinergic system changes during development. Partial transection of the fimbria fornix bundle in the second postnatal week resulted in a reduction of BDNF and NGF mRNA levels in the hippocampus, suggesting that septal cholinergic input is involved in the regulation of hippocampal BDNF and NGF mRNA levels. Because the fimbria fornix bundle also contains fibers other than cholinergic ones, we further evaluated the importance of the cholinergic influence by injecting pilocarpine, a muscarinic agonist. Pilocarpine markedly increased hippocampal BDNF and NGF mRNA levels in both early postnatal and adult rats. In situ hybridization experiments demonstrated that pilocarpine led to an increase in BDNF expression in the CA1-CA4 regions of the hippocampus and in the dentate gyrus. However, pilocarpine increased NGF mRNA only in those neurons of the dentate gyrus and CA1-CA4 regions that also expressed NGF mRNA in the controls. Thus, the pattern of BDNF and NGF mRNA expression following pilocarpine administration is different from that observed following injection of kainic acid (KA) in adult animals. Administration of KA during the first 2 postnatal weeks affected neither NGF nor BDNF mRNA levels, in spite of producing generalized seizures. In contrast to NGF and BDNF, neurotrophin-3 mRNA levels were not changed by pilocarpine administration. The pilocarpine-mediated increase in BDNF mRNA was inhibited not only by the mus-

\footnotetext{
Nov. 18, 1992; revised Feb. 18, 1993; accepted Mar. 10, 1993.

We are grateful to Dorothea Stratmann and Christel Bauereiss for skillful technical assistance. We thank Ingrid Hajjar for secretarial work, and Dr. Tony Hughes for the linguistic revision of the manuscript. M.P.B. is supported by the Conselho Nacional de Desenvolvimento Cientifico e Tecnológico (CNPq), Brazil. E.C. is supported by the Alexander von Humboldt Foundation, and F.Z. is a recipient of a long-term fellowship from the European Molecular Biology Organization.

Correspondence should be addressed to Maria da Penha Berzaghi, Max Planck Institute for Psychiatry, Department of Neurochemistry, Am Klopferspitz $18 \mathrm{~A}$, D-8033 Planegg Martinsried, Germany.

Copyright (C) 1993 Society for Neuroscience $0270-6474 / 93 / 133818-09 \$ 05.00 / 0$
}

carinic antagonist scopolamine, but also by MK-801, a noncompetitive antagonist of NMDA receptors, suggesting an involvement of these receptors in BDNF regulation. Moreover, intraventricular injection of NMDA increased BDNF mRNA expression in the hippocampus of postnatal day 7 rats. Thus, during early postnatal development the activitydependent regulation of neurotrophins is not mediated by KA but NMDA receptors, which are also influenced by the cholinergic system.

IKey words: neurotrophic factors, gene regulation, hippocampus, fimbria fornix, pilocarpine, muscarinic receptors]

Previous studies have shown that BDNF (brain-derived neurotrophic factor) and NGF provide trophic support to septal cholinergic neurons that project mainly to hippocampus and cortex. Both NGF (Hefti et al., 1985; Hartikka and Hefti, 1988; Hatanaka et al., 1988) and BDNF (Alderson et al., 1990; Knüsel et al., 1991)) influence the survival of septal cholinergic neurons in culture and increase the activity of the enzyme responsible for the synthesis of ACh, ChAT. In vivo studies have shown that radiolabeled NGF (Schwab et al., 1979; Seiler and Schwab, 1984) and BDNF (DiStefano et al., 1992) are retrogradely transported by septal cholinergic neurons. Administration of NGF rescues septal cholinergic neurons that would otherwise degenerate following fimbria fornix (FF) transection (Hefti, 1986). However, neuroprotective effects of BDNF after FF lesion have not yet been reported. Neurotrophin-3 (NT-3), the third member of the NGF gene family, is also expressed in the hippocampus (Hohn et al., 1990; Kaisho et al., 1990; Maisonpierre et al., 1990b; Rosenthal et al., 1990). However, thus far there is no evidence that NT-3 influences survival and differentiation of septal cholinergic neurons in culture (Alderson et al., 1990; Knüsel et al., 1991).

In vitro experiments have demonstrated that depolarization with high potassium concentrations results in an increase in the levels of NGF (Zafra et al., 1990; Lu et al., 1991) and BDNF mRNA (Zafra et al., 1990). Activation of glutamate receptors plays an important role in upregulating the expression of BDNF and NGF, whereas stimulation of the GABAergic system decreases the levels of BDNF and NGF MRNA in the hippocampus of adult rats (Zafra et al., 1991). Accordingly, the levels of NGF (Zafra et al., 1990; Gall et al., 1991) and BDNF mRNAs (Zafra et al., 1990; Ballarin et al., 1991; Dugich-Djordjevic et al., 1992a) were shown to be increased by kainic acid (KA), a 
non-NMDA glutamate receptor agonist. This KA-mediated increase could be blocked by 2,3-dihydroxy-6-nitrosulfanoylbenzo(f)quinoxaline (NBQX), a competitive inhibitor of the nonNMDA receptors (Ernfors et al., 1991; Zafra et al., 1991), but not by NMDA receptor blockers (Zafra et al., 1991). Studies on NGF (Gall and Isackson, 1989) and BDNF (Isackson et al., 1991) expression following limbic seizures and kindling epileptogenesis (Ernfors et al., 1991) have demonstrated the importance of neuronal activity in the regulation of BDNF and NGF in the rat hippocampus. However, seizures are clearly not necessary (Zafra et al., 1990; Lindefors et al., 1992) and, particularly for the immature brain, not sufficient (Dugich-Djordjevic et al., $1992 \mathrm{~b}$ ) to increase BDNF and NGF mRNA levels. Moreover, the regulatory processes seem to be more complex than originally thought as recent studies have shown that not only NBQX but also MK-801, a noncompetitive inhibitor of the NMDA subtype of glutamate receptors, reduces BDNF and NGF mRNA as well as NGF protein levels in the adult rat hippocampus (Zafra et al., 1991). Thus, both NMDA and non-NMDA receptors are involved in NGF and BDNF regulation in the adult rat hippocampus. The basal expression of neuronal BDNF and NGF sccms to be determined by a finely tuned balance between different neurotransmitter systems. The enhancing effects of the glutamatergic system are opposed by the inhibitory actions of the GABAergic system (Zafra et al., 1991).

The aim of the present study was to analyze the contribution of the cholinergic system to the regulation of NGF and BDNF in the hippocampus, particularly during early postnatal development. Previous experiments have shown that besides KA, a cholinergic muscarinic receptor agonist, carbachol, also increased BDNF mRNA levels in rat hippocampal neurons in culture (Zafra et al., 1990). Recently, Lindefors et al. (1992) have demonstrated that the activation of cholinergic neurons by quisqualate injections into the medial septum increased BDNF and NGF mRNA levels in adult rat hippocampus and that this effect was blocked by the systemic administration of scopolamine. These latter findings are in agreement with our working hypothesis, that the septal cholinergic neurons themselves might influence the production of BDNF and NGF in the hippocampus during postnatal development. In favor of this view, we show here that transection of cholinergic fibers projecting from the septum to the hippocampus decreased the levels of BDNF and NGF mRNA in the early postnatal development. Pilocarpine, a muscarinic agonist that crosses the blood-brain barrier, increased the levels of BDNF and NGF mRNA in the rat hippocampus throughout postnatal development. In contrast to observations in adult rats (Zafra et al., 1990; Ballarín et al., 1991; Gall et al., 1991; Dugich-Djordjevic et al., 1992a), KA does not increase BDNF and NGF mRNA expression in the early postnatal period (Dugich-Djordjevic et al., 1992b). The effect of pilocarpine could be blocked by scopolamine and, interestingly, also by MK-801, suggesting that pilocarpine might influence the release of glutamate in the hippocampus. Moreover, intraventricular injections of NMDA elevated BDNF mRNA levels in the hippocampus of postnatal day 7 (P7) rats.

\section{Materials and Methods}

Drugs. Pilocarpine hydrochloride, methylscopolamine nitrate, scopolamine, $N$-methyl-D-aspartate, and KA were obtained from Sigma (St. Louis, MO). MK-801 was obtained from Research Biochemicals (Nantick, MA). NBQX was a kind gift from Dr. T. Honoré, Novo Nordisk (Bagsveard, Denmark).
Treatment of animals. All the animal experiments reported in this study were conducted in accordance with the statement regarding the care and use of animals, following the recommendations of Gärtner (1991). Male Wistar rats aged 7-90 days were used in this study. The day of birth was defined as P0. Pilocarpine was administered intraperitoneally, at 150 or $340 \mathrm{mg} / \mathrm{kg}$. Methylscopolamine $(1 \mathrm{mg} / \mathrm{kg}$ ) was administered subcutaneously $30 \mathrm{~min}$ prior to pilocarpine. Both pilocarpine and methylscopolamine were freshly dissolved in saline before use. Pretreatment with scopolamine $(25 \mathrm{mg} / \mathrm{kg}$, s.c.) and MK-801 $(2 \mathrm{mg} / \mathrm{kg}$, i.p.) was performed 45 and $20 \mathrm{~min}$, respectively, before pilocarpine administration. KA was injected intraperitoneally, at $3 \mathrm{mg} / \mathrm{kg}$ in $\mathrm{P} 7$ and $\mathrm{P} 16$ animals and at $12 \mathrm{mg} / \mathrm{kg}$ in $\mathrm{P} 90$ rats. The doses of KA were adjusted according to the age-related sensitivity to the drugs (Holmes and Thompson, 1988). Ninety minutes after the KA injection, the animals received diazepam $(10 \mathrm{mg} / \mathrm{kg}$, i.p.) to suppress seizure activity ( $\mathrm{afra}$ et al., 1990). Control animals received an equal volume of saline. Each group of animals was composed of 10-15 rats.

Surgical procedures. Unilateral partial transections of the fimbria fornix (FF) were performed under ether anesthesia by a knife lesion in P9 rats $(n=23)$. Lesions were made via a coronal incision in the parietal bone cxtending $3 \mathrm{~mm}$ from the midline and $2.5 \mathrm{~mm}$ behind the position of bregma. Under direct observation with an operating microscope, a sterile scalpel blade was lowered to the depth of $6 \mathrm{~mm}$ at the lateral margin of this incision and moved medially to partially transect the FF. Sham operations in which a small incision $3 \mathrm{~mm}$ in length was made superficially in the overlying cortex were performed in littermates. Following surgery, pups were returned to their mothers and killed at P16. The pups were either taken for determination of mRNA levels $(n=19)$ or perfusion fixed for histological examination $(n=4)$. In an additional group of P7 pups, unilateral injections of $1 \mu \mathrm{l} \mathrm{NMDA}(12 \mu \mathrm{g} / \mu \mathrm{l})(n=$ 6 ) into the lateral ventricle were performed stereotaxically under ether anesthesia. Coordinates were derived from the atlas of Paxinos ct al. (1991) (AP, $-1.5 ; \mathrm{L}, 2.0 ; \mathrm{V},-2.5)$. Drugs were delivered in a volume of $1.0 \mu \mathrm{l}$ at a rate of $0.1 \mu \mathrm{l} / \mathrm{min}$ via a 29 gauge stainless steel cannula conncetcd by a Tefion tube (filled with paraflin oil) to a $5 \mu$ l syringe driven by a Harvard microinfusion pump. Control littermates received unilateral injections of the same volume of saline $(n=6)$ or remained unoperated $(n=6)$.

RNA analysis. Total RNA was extracted from the hippocampus of rats as described by Chomczynski and Sacchi (1987), separated on a $1.3 \%$ agarose gel, and transferred to a Hybond $\mathrm{N}$ nylon membrane (Lindholm et al., 1988). A shortened cRNA standard was added to the samples before extraction to assess RNA recovery. The filters were prehybridized for $2 \mathrm{hr}$ at $65^{\circ} \mathrm{C}$ in $50 \%$ formamide, $3 \times \mathrm{SSC}(1 \times \mathrm{SSC}=$ $150 \mathrm{~mm} \mathrm{NaCl}, 15 \mathrm{~mm}$ sodium citrate), $5 \mathrm{~mm} \mathrm{Na}_{2}$ EDTA, $0.5 \%$ SDS, $5 \times$ Denhardt's solution, $250 \mu \mathrm{g}$ of denatured salmon sperm DNA per $\mathrm{ml}, 50 \mathrm{~mm}$ phosphate buffer, $\mathrm{pH} 7.0$, and hybridized overnight at $65^{\circ} \mathrm{C}$ in the same buffer together with ${ }^{32} \mathrm{P}$-labeled cRNA probes for BDNF, NGF, or NT-3. Filters were washed twice for $10 \mathrm{~min}$ in $2 \times \mathrm{SSC}, 0.1 \%$ SDS at $65^{\circ} \mathrm{C}$ and for $15 \mathrm{~min}$ in $0.2 \times \mathrm{SSC}, 0.1 \% \mathrm{SDS}$ at $72^{\circ} \mathrm{C}$ and exposed to $x$-ray film. The amount of RNA was estimated with a laser scanning device (LKB, Bromma, Sweden). The two transcripts of BDNF were regulated in a similar manner and the upper transcript was used for quantitative evaluation. mRNA values were expressed per milligram wet weight of tissue and corrected for RNA recovery. Student's $t$ test was used for the statistical analysis.

In situ hybridization. In situ hybridization was performed in $12-\mu \mathrm{m}$ thick frozen sections, which were postfixed in $4 \%$ buffered paraformaldehyde, treated with acetic anhydride, and hybridized overnight at $42^{\circ} \mathrm{C}$ in a buffer containing $50 \%$ formamide, $4 \times$ SSC, $50 \mathrm{~mm}$ phosphate buffer $(\mathrm{pH} 7.0), 1 \%$ lauryl sarcosine, $1 \times$ Denhardt's solution, $250 \mu \mathrm{g}$ of yeast tRNA per ml, $0.5 \mathrm{mg}$ of denatured salmon sperm DNA per $\mathrm{ml}, 10 \%$ dextran sulfate, and $100 \mathrm{mM}$ dithiothreitol. A single-stranded cDNA probe random prime labeled with ${ }^{35} \mathrm{~S}$ from BDNF or NGF sense cRNA with reverse transcriptase to a specific activity of $2-3 \times 10^{9} \mathrm{cpm} / \mu \mathrm{g}$ was used (Schnürch and Risau, 1991). Sections were washed under increasing stringency up to $0.5 \times \mathrm{SSC}$ at $60^{\circ} \mathrm{C}$, dehydrated, and for 3 weeks exposed to Ultrofilm B-max film (Amersham, UK).

\section{Results}

Neonatal transection of $F F$ reduces $B D N F$ and NGF $M R N A$ in developing hippocampus

We have previously shown that carbachol, a synthetic cholinergic receptor agonist, increases BDNF $\mathrm{mRNA}$ in cultured hip- 


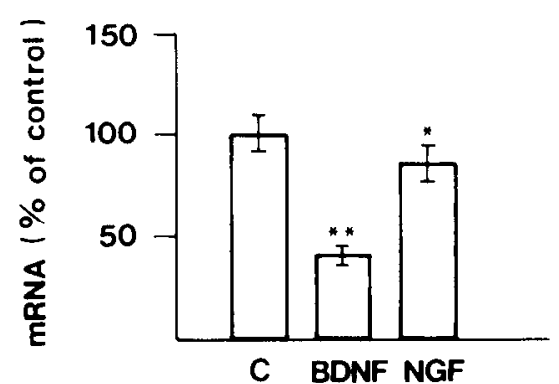

Figure 1. Effect of FF transection in P9 rats on hippocampal BDNF and NGF mRNA levels measured on P16. RNA was extracted and analyzed as described in Materials and Methods. Values given represent means \pm SEM of three experiments. $C$, control. ${ }^{*}, p<0.02 ;{ }^{* *}, p<$ 0.001 .

pocampal neurons from prenatal rats (Zafra et al., 1990). In order to evaluate the importance of the septal input to the hippocampus in regulating BDNF and NGF expression during postnatal development, the nerve fibers projecting from septum to hippocampus were transected at $\mathrm{P} 9$. Figure 1 shows that the septohippocampal transection at $\mathrm{P} 9$ led to a decrease to $40 \%$ in the hippocampal level of BDNF mRNA in P16 rats when compared to nonoperated, age-matched controls. Likewise, the hippocampal NGF mRNA levels were reduced to $80 \%$ of controls.

\section{Pilocarpine increases BDNF and NGF but not NT-3 mRNA levels in rat hippocampus}

The septal projection to the hippocampus is not exclusively cholinergic. The GABAergic input from the septum terminates upon GABAergic interneurons in the hippocampus (Freund and Antal, 1988). In order to evaluate whether BDNF and NGF mRNA levels are indeed regulated by a cholinergic mechanism in vivo, the muscarinic agonist pilocarpine was administered to rats. Injection of $320 \mathrm{mg} / \mathrm{kg}$ of pilocarpine in $\mathrm{P} 7$ rats increased the hippocampal BDNF (four- to fivefold) and NGF (two- to threefold) but not NT-3 mRNA levels (Fig. 2A). Pilocarpine rapidly clevated $B D N F m R N A$ levcls, which remaincd clevated for at least $24 \mathrm{hr}$ (Fig. 2B). The increase in BDNF mRNA by pilocarpine after $3 \mathrm{hr}$ was four- to fivefold in P7-P19 rats and three- to fourfold in adult rats (Fig. 2C).

In situ hybridization experiments showed that pilocarpine increased BDNF mRNA in all hippocampal subfields as well as in the dentate gyrus, but the increase was more prominent in the pyramidal neurons in the CA1 region. This pattern was similar in both P7 and adult rats (Fig. 3). NGF mRNA, which in control animals is expressed in single neurons in the hippocampal CA1-CA4 subfields, showed the same pattern of expression after pilocarpine administration, suggesting that pilocarpine increases NGF mRNA levels in those neurons that normally express NGF mRNA (Fig. 4).

Although convulsive doses of pilocarpine have been shown to produce neurotoxicity in adult rats, this does not seem to be the case in neonatal animals (Cavalheiro et al., 1987). To study the role of generalized seizures in the pilocarpine-mediated increase in BDNF mRNA, P7 rats were treated with a dose of pilocarpine that does not induce generalized seizures. Pilocarpine at $150 \mathrm{ml} / \mathrm{kg}$, which produced no generalized seizures, also significantly increased BDNF mRNA in hippocampus (Fig. 5).

Figure $6 A$ shows that the pretreatment with scopolamine, a muscarinic receptor antagonist, completely inhibited the pilocarpine-induced increase in BDNF mRNA in the hippocampus
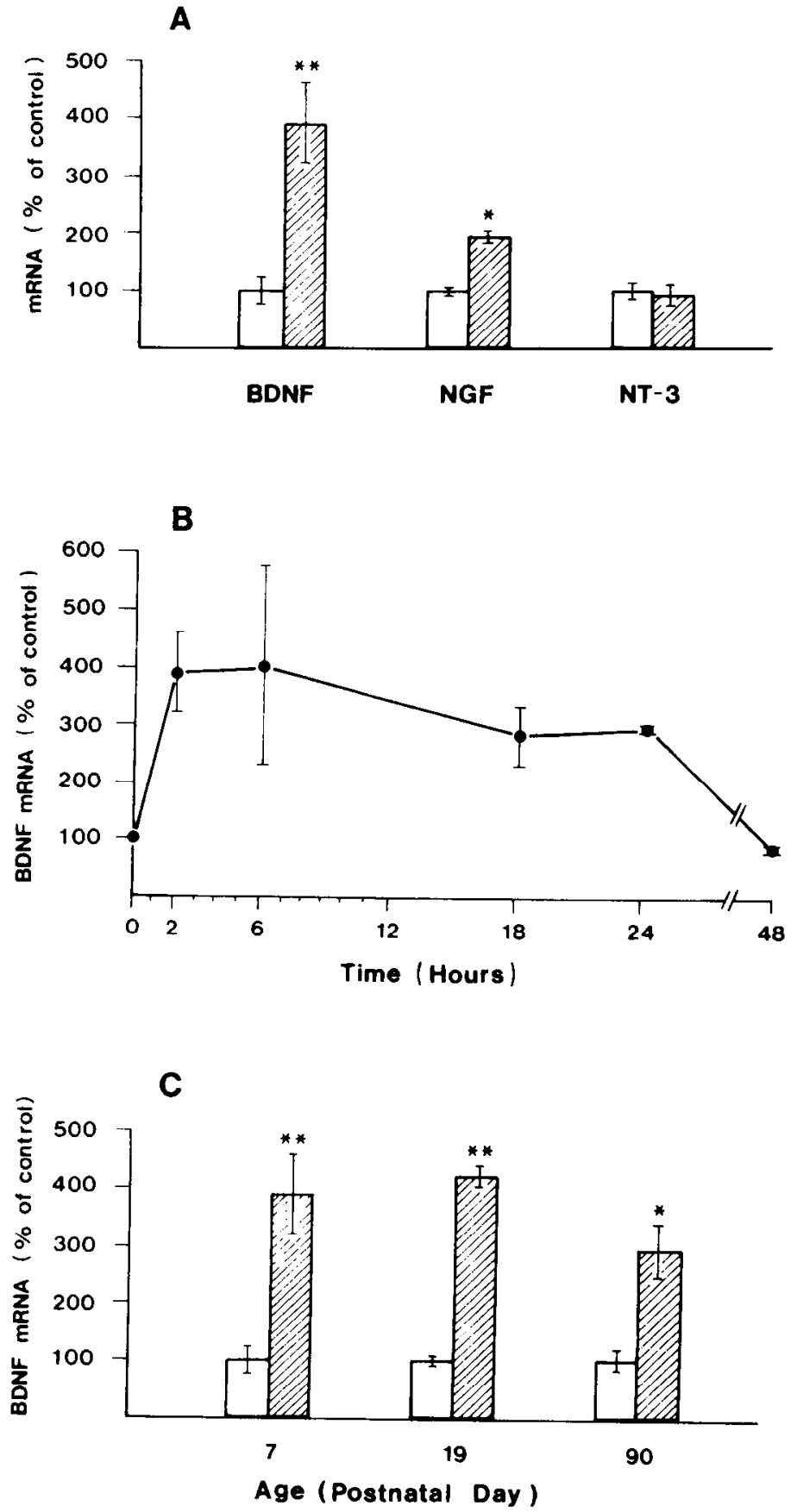

Figure 2. Effect of pilocarpine on BDNF, NGF, and NT-3 mRNA levels in rat hippocampus. $A, \mathrm{P} 7$ rats were treated with pilocarpine and $3 \mathrm{hr}$ later killed for BDNF, NGF, and NT-3 mRNA determination. $B$. Time course of the pilocarpine-mediated increase in BDNF mRNA levels in $\mathrm{P} 7$ rats. $C$, Effect of pilocarpine on BDNF mRNA levels in $\mathrm{P7}, \mathrm{P} 19$, and $\mathrm{P} 90$ rats. The rats were treated with methylscopolamine $(1 \mathrm{mg} / \mathrm{kg}$, s.c.) $30 \mathrm{~min}$ before injection of pilocarpine $(340 \mathrm{mg} / \mathrm{kg}$, i.p.) and killed $3 \mathrm{hr}$ later. RNA was extracted and analyzed as described in Materials and Methods. Values given represent mean \pm SEM of three experiments. ${ }^{*}, p<0.02 ;{ }^{* *}, p<0.001$. Hatched bars, pilocarpine; open bars, control.

of P7 rats. Moreover, scopolamine alone showed a tendency to reduce the basal level of BDNF mRNA, but not at statistically significant levels $(p>0.05)$. Because focally injected pilocarpine has been shown to induce glutamate release in the rat hippocampus (Millan et al., 1991), we also tested whether the effect 

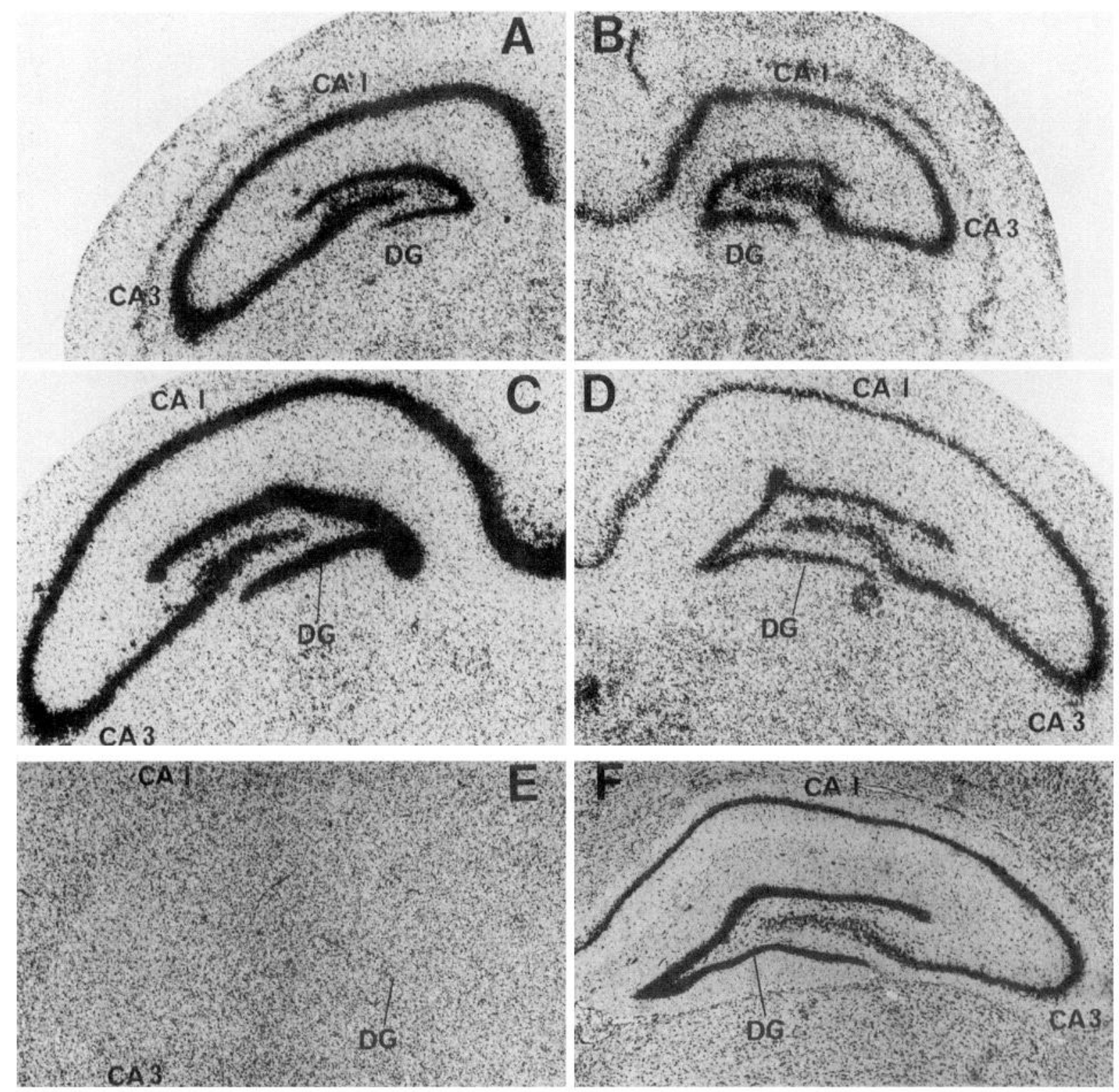

Figure 3. In situ hybridization of BDNF mRNA in rat hippocampus. A, $\mathrm{P} 7$ rat treated with pilocarpine (left section). B, P7 control rat (right section). $C$, P90 rat treated with pilocarpine (left section). D, P90 control rat (right section). The increase in BDNF mRNA was the same in both hemispheres. The rats were treated with methylscopolamine $(1 \mathrm{mg} / \mathrm{kg}$, s.c.) $30 \mathrm{~min}$ before pilocarpine injection $(340 \mathrm{mg} / \mathrm{kg}$, i.p.). Three hours later the rats were killed and the brain was taken for in situ hybridization of BDNF mRNA in the hippocampus as described in detail in Materials and Methods. E, A hippocampal section hybridized with a sense probe. $F$, A hippocampal section stained with cresyl violet. $D G$, dentate gyrus; $C A 1$, $C A 3$, regions $\mathrm{CA} 1$ and $\mathrm{CA} 3$ of the hippocampus. Magnification, $20 \times$.

of pilocarpine could be influenced by glutamate receptor antagonists. The results presented in Figure $6 B$ demonstrate that this is indeed the case. Thus, the hippocampal pilocarpine-mediated increase in BDNF mRNA was reduced by the pretreatment with MK-801, a noncompetitive NMDA receptor antagonist.

\section{$K A$ does not elevate BDNF $M R N A$ in the developing hippocampus}

Previous studies have shown that KA increases BDNF (Zafra et al., 1990; Ballarín et al., 1991; Dugich-Djordjevic et al., 1992a) and NGF (Zafra et al., 1990; Gall et al., 1991) mRNA levels in adult rat hippocampus. To study whether this is also the case in the rat hippocampus during development, animals of different ages were treated with KA. As shown in Figure 7, KA elevated BDNF mRNA levels in adult rat hippocampus but it was without effect in $\mathrm{P} 7$ pups. A more detailed analysis showed that the increase in hippocampal BDNF mRNA did not become apparent before P16 (Fig. 7). In situ hybridization experiments performed on hippocampal sections confirmed these results. These experiments showed no increase in hippocampal BDNF mRNA levels in P7 rats but a large increase in all hippocampal subfields and dentate gyrus in adult animals (Fig. 8). Similar findings were recently reported by Dugich-Djordjevic et al. (1992b). 
PILO

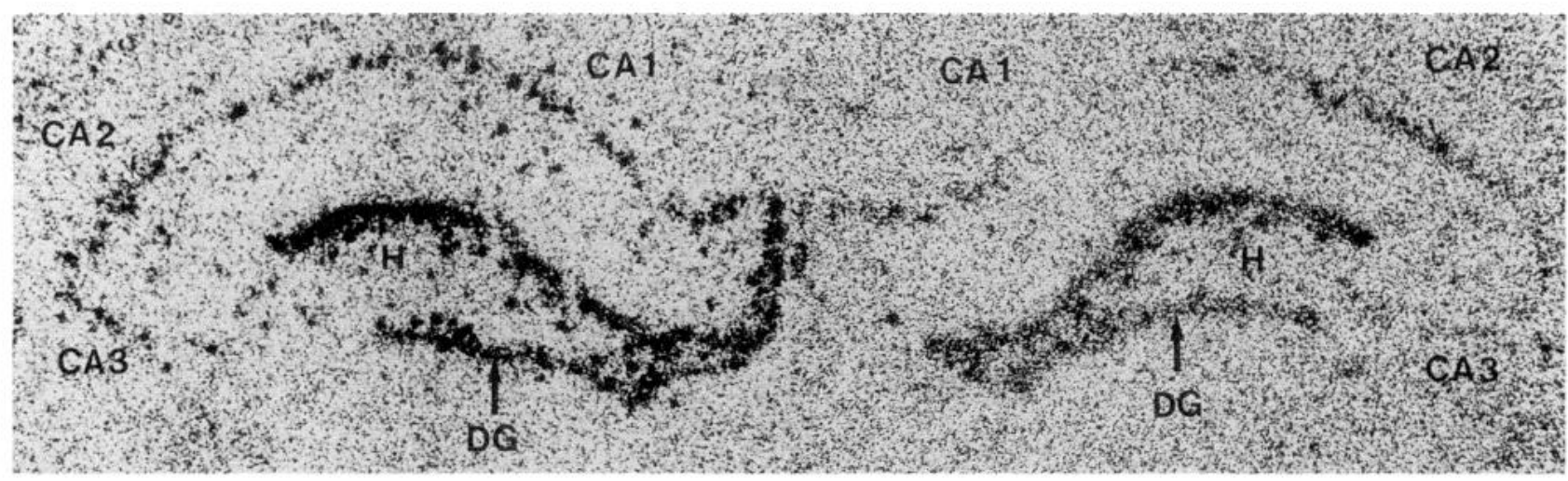

Figure 4. In situ hybridization of the NGF mRNA in the hippocampus. Left side, $\mathrm{P} 90$ rat treated with methylscopolamine (1 mg/kg, s.c.) before pilocarpine injection $(340 \mathrm{mg} / \mathrm{kg}$, i.p.). Three hours later the rat was killed and the brain was taken for in situ hybridization of NGF mRNA in the hippocampus as described in detail in Materials and Methods. Right side, Control P90 rat. Note punctate appearance of the hybridization signal in control rat and augmentation of the control pattern after the pilocarpine treatment. This effect was observed bilaterally. $D G$, dentate gyrus; $C A 1-$ CA3, hippocampal fields $1-3 ; H$, hilus of the dentate gyrus. Magnification, $20 \times$.

\section{Intraventricular injection of NMDA increases BDNF $m R N A$ levels in the developing hippocampus}

Unilateral injections of NMDA into the lateral ventricle of P7 rats increased BDNF mRNA (threefold) in the ipsilateral and to a lesser extent also in the contralateral hippocampus (Fig. 9). This observation demonstrates the involvement of NMDA receptors in the regulation of the synthesis of BDNF in early postnatal development.

\section{Discussion}

The results of the present article provide evidence that cholinergic neuronal activity is essentially involved in the regulation of BDNF and NGF mRNAs in the developing and adult rat hippocampus. We show here that transection of the FF pathway at $\mathrm{P} 9$ leads to a decrease in the hippocampal BDNF and NGF but not NT-3 mRNA levels in P16 rats and that pilocarpine, a muscarinic agonist, upregulates the levels of these mRNAs throughout postnatal development. The pilocarpine-mediated increase was blocked by scopolamine, a muscarinic antagonist, and also by MK-801, a noncompetitive NMDA receptor antagonist in the developing rat. Conversely, intraventricular injection of NMDA increased BDNF mRNA levels. These results support the notion that hippocampal BDNF and NGF mRNA expression is indeed regulated by neuronal activity, involving in the early postnatal period the cholinergic system and NMDA receptors.

The initial growth of septal cholinergic fibers toward the immature hippocampus occurs as early as embryonic day 15 , but the axons do not reach the hippocampus before Pl (Koh and Loy, 1989). The increase in hippocampal ChAT levels develops later. ChAT activity in neonatal rats is about $10 \%$ of the adult levels, increasing about threefold by the end of the first week. Adult levels of ChAT are reached by the end of the third postnatal week (Auburger et al., 1987). The development of AChEstained fibers within the hippocampal formation parallels the pattern of innervation by the septal nuclei (Milner et al., 1983). Likewise, muscarinic receptor binding in the hippocampus increases threefold during early development and reaches adult levels and patterns around P17 (Aronstan et al., 1979). Concomitant with the increases in various cholinergic parameters, the levels of both BDNF (Maisonpierre et al., 1990a) and NGF mRNA (Auburger et al., 1987) substantially increase postnatally in the rat hippocampus. As shown here, the increase in BDNF was greatly reduced following an $\mathrm{FF}$ lesion in $\mathrm{P} 9$ rats, suggesting that the in-growing cholinergic fibers enhance BDNF expression in the developing rat hippocampus. Results obtained with the surgical approach are consistent with the effect of administration of pilocarpine, which activates mainly the muscarinic type I receptors (van Chaldorp et al., 1985) increasing BDNF and to a lesser extent NGF mRNA levels in the developing rat hippocampus.

The effect of pilocarpine was inhibited not only by scopolamine, a muscarinic receptor antagonist, but also by MK-801, a noncompetitive NMDA receptor antagonist. Focally applied pilocarpine has earlier been shown to stimulate glutamate release in the adult rat hippocampus (Millan et al., 1991). Such a mechanism is also compatible with our observation that intraventricular administration of NMDA increases BDNF mRNA levels. Moreover, it has been suggested that the activation of muscarinic receptors could enhance the NMDA-mediated calcium influx (Ben-Ari et al., 1992). Both BDNF and NGF mRNA levels are regulated by calcium influx in neuronal cultures of rat hippocampus (Zafra et al., 1990, 1992). The rise in intracellular calcium concentration can be accomplished by activation of NMDA receptor channels, which are permeable to calcium and present in the dendrites of CA1 pyramidal neurons (Dermott et al., 1986; Regher and Tank, 1990). It has been shown that in CA1 pyramidal neurons, activation of muscarinic receptors increases NMDA currents via the phosphatidyl inositol pathway (Markram and Segal, 1992). These observations might partly explain the blocking effect of MK-801 on the pilocarpine-induced elevation of BDNF mRNA levels in rat hippocampus. Thus, the effect of pilocarpine on BDNF mRNA might be mediated by the release of glutamate-activating NMDA receptors, or be due to the enhancing effect of the cholinergic input on the function of NMDA receptors.

In situ hybridization showed that pilocarpine increased BDNF mRNA levels in all hippocampal subfields, but the increase was most prominent in the granule cell layer of the dentate gyrus and in the CAl subfield. The pattern of the increase after pilocarpine administration was similar in the young and adult 


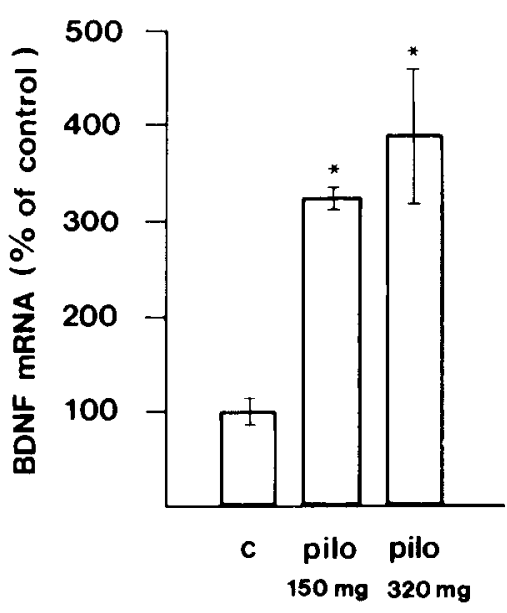

Figure 5. Effect of different doses of pilocarpine on BDNF mRNA levels in the hippocampus. P7 rats were treated with methylscopolamine $(1 \mathrm{mg} / \mathrm{kg}$, s.c.) before pilocarpine injection $(150$ and $340 \mathrm{mg} / \mathrm{kg}$, i.p.). Three hours later the pups were killed and RNA was extracted and analyzed as described in Materials and Methods. Values represent mean \pm SEM of three experiments. ${ }^{*}, p<0.001$.

brain. This pattern coincides with the distribution of the NMDA receptors, which are densest in the dentate gyrus and CAl area (Monaghan et al., 1983; Insel et al., 1990). KA increased BDNF mRNA equally strongly in all subfields of the hippocampus of adults but did not affect BDNF mRNA levels in the hippocampus of developing rats. NGF mRNA appeared to be increased after pilocarpine administration in those neurons that normally express lower levels of NGF mRNA. This is in sharp contrast to the effect of KA in adult rats, where NGF mRNA levels increase only in the granule cells of the dentate gyrus but not in the hilus and CA1-CA3 subfields (Ballarín et al., 1991; Gall et al., 1991).

Seizures induced by pilocarpine have previously been used as an experimental model for epilepsy (Turski et al., 1983, 1984). The results of these studies have shown that even high doses of pilocarpine given to neonatal rats do not produce any neurotoxicity in spite of inducing limbic seizures (Cavalheiro et al., 1987). However, the increase in BDNF mRNA by pilocarpine did not result from generalized seizures alone since $150 \mathrm{mg} / \mathrm{kg}$ of pilocarpine significantly increased the hippocampal BDNF mRNA levels without producing generalized seizures. Seizures induced by KA (Zafra et al., 1990; Gall et al., 1991; DugichDjordjevic et al., 1992a), electrolytic lesions (Gall and Isackson, 1989), and kindling (Ernfors et al., 1991) have been shown to increase BDNF and NGF mRNA levels in the hippocampus of adult rats. However, KA-induced seizures in developing rats were not accompanied by an increase in hippocampal BDNF mRNA levels, as observed in adults (Dugich-Djordjevic et al., 1992b). In addition, a similar disconnection between seizure activity and increases in BDNF and NGF in adult rats was previously shown using KA-treated rats given MK-801 (Zafra et al., 1990), although electrographic seizure activity could not be excluded since no physiological recordings were performed. Furthermore, the stimulation of afferent cholinergic and glutamatergic pathways to the hippocampus with quisqualate also induced increases in BDNF and NGF mRNA levels without producing seizures (Lindefors et al., 1992). All these data demonstrate that seizures are clearly not necessary and, at least for
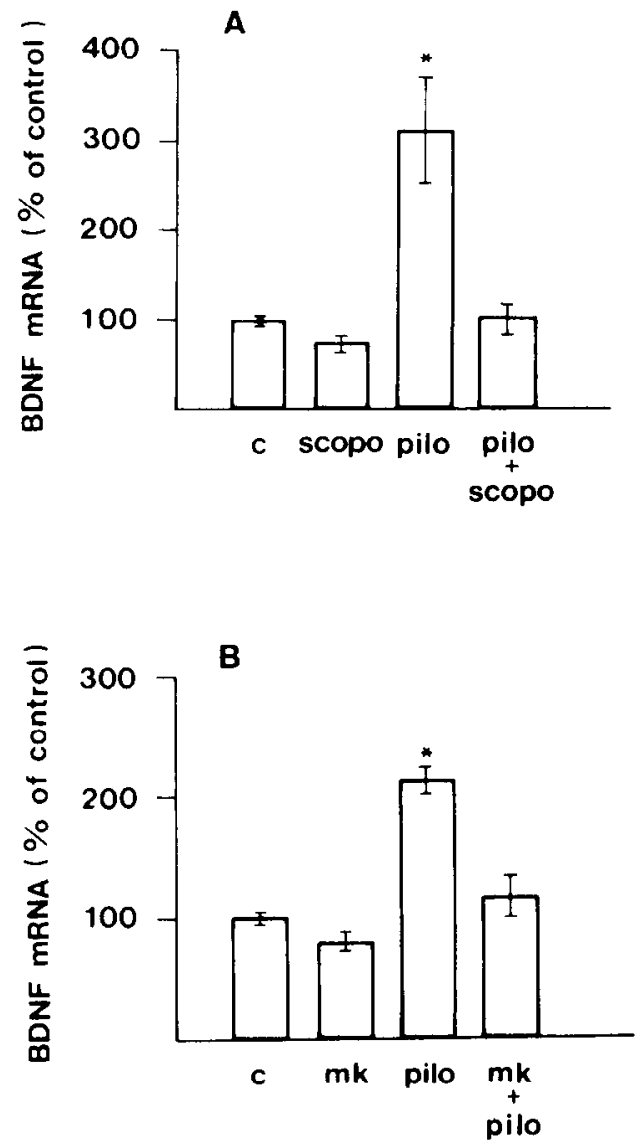

Figure 6. Effect of inhibitors on the pilocarpine-mediated increase on BDNF mRNA in the hippocampus of P7 rats. $A$, Effect of pretreatment ( $45 \mathrm{~min})$ with scopolamine $(25 \mathrm{mg} / \mathrm{kg}$, s.c.) on the pilocarpine-induced expression of BDNF mRNA in the hippocampus of P7 rats. $B$, Effect of pretreatment $(15 \mathrm{~min})$ with MK-801 $(2 \mathrm{mg} / \mathrm{kg}$, i.p. $)$ on the pilocarpine-induced increase on BDNF mRNA levels in the hippocampus of P7 rats. Three hours after pilocarpine injection $(340 \mathrm{mg} / \mathrm{kg}$, i.p.) the pups were killed and RNA was extracted and analyzed as described in Materials and Methods. Values represent mean \pm SEM of three experiments. ${ }^{*}, p<0.01$.

the immature brain, not sufficient to upregulate hippocampal BDNF and NGF mRNA levels.

In contrast to BDNF and NGF, the levels of NT-3 mRNA were not changed either by FF transection or by pilocarpine

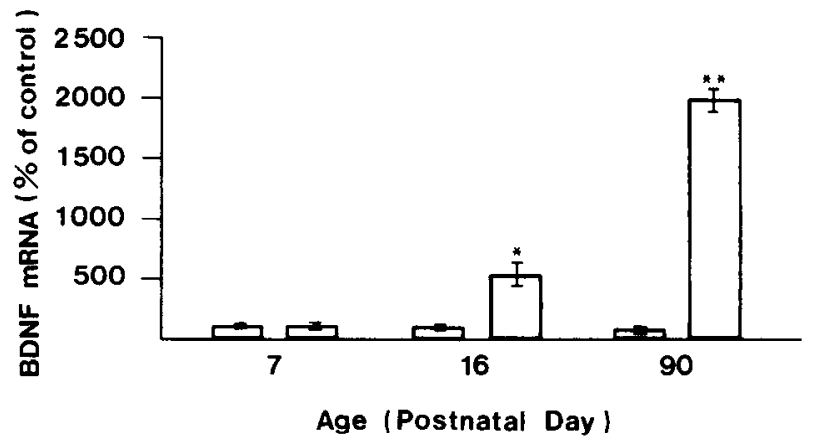

Figure 7. Effect of KA on hippocampal BDNF mRNA levels at different postnatal ages. The doses of KA were adjusted to the age-related sensitivity to the drug (P7 and P16,3 mg/kg; P90, $12 \mathrm{mg} / \mathrm{kg}$; i.p.). Ninety minutes after $\mathrm{KA}$ injection the rats received diazepam $(10 \mathrm{mg} / \mathrm{kg}$, i.p.). Three hours after KA administration the rats were killed and RNA was extracted and analyzed as described in Materials and Methods. Values represent mean \pm SEM of three experiments. ${ }^{*}, p<0.01 ;{ }^{* *}, p<0.001$. 
KA

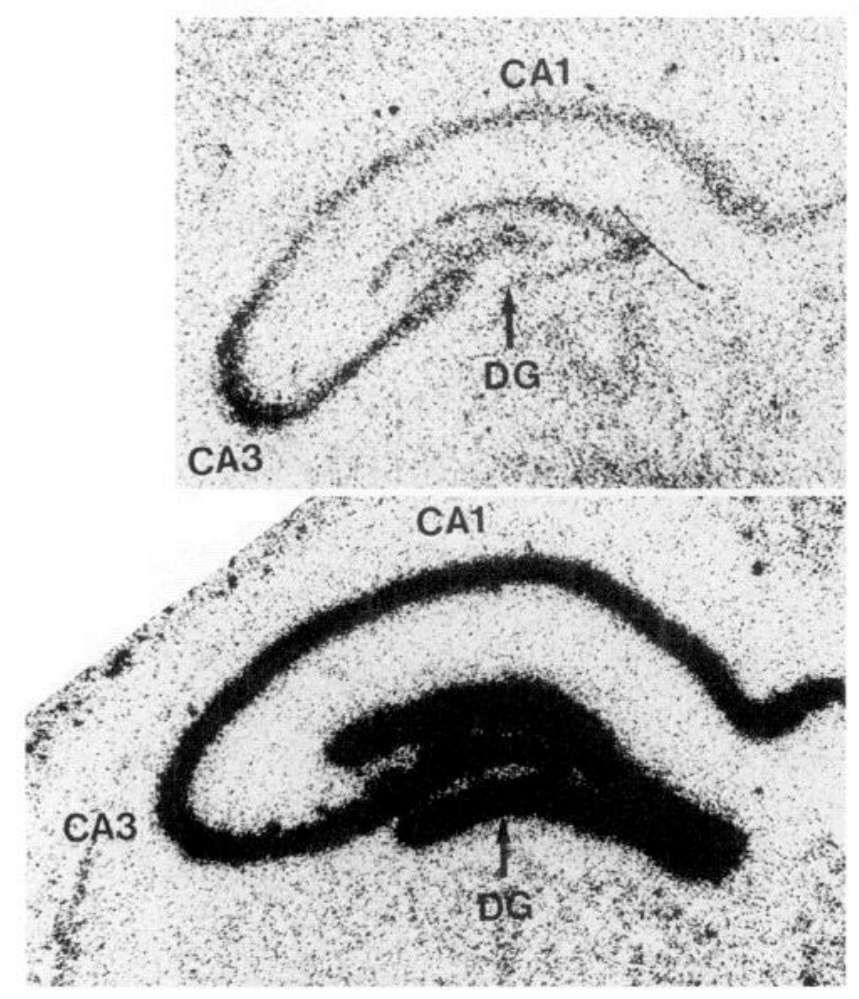

CONTROL

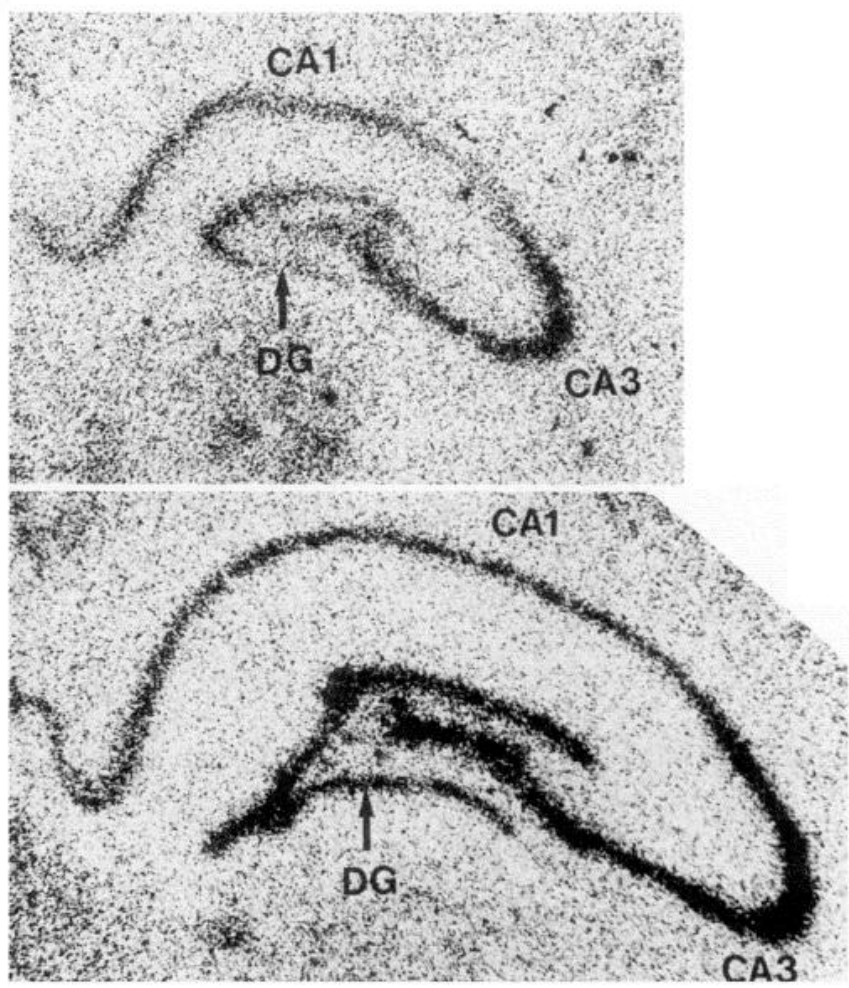

Figure 8. In situ hybridization of BDNF mRNA in the rat hippocampus. Top:Left, P7 rat treated with KA (3 mg/kg, i.p.). Right, P7 control rat. Bottom:Left, P90 rat treated with KA. Right, P90 control rat. The doses of KA were adjusted to the age-related sensitivity to the drug (P7, 3 mg/ $\mathrm{kg} ; \mathrm{P} 90,12 \mathrm{mg} / \mathrm{kg})$. Ninety minutes after KA administration the rats received diazepam $(10 \mathrm{mg} / \mathrm{kg}$, i.p.). Three hours after KA injection the rats were killed and the brains were taken for the in situ hybridization of the BDNF mRNA as described in Materials and Methods. KA strongly increases BDNF mRNA in the hippocampal subfields of the P90 rat, but has no effect at P7. This increase was observed bilaterally. $C A 1$, $C A 3$, hippocampal fields 1 and 3; $D G$, dentate gyrus. Magnification, $20 \times$.

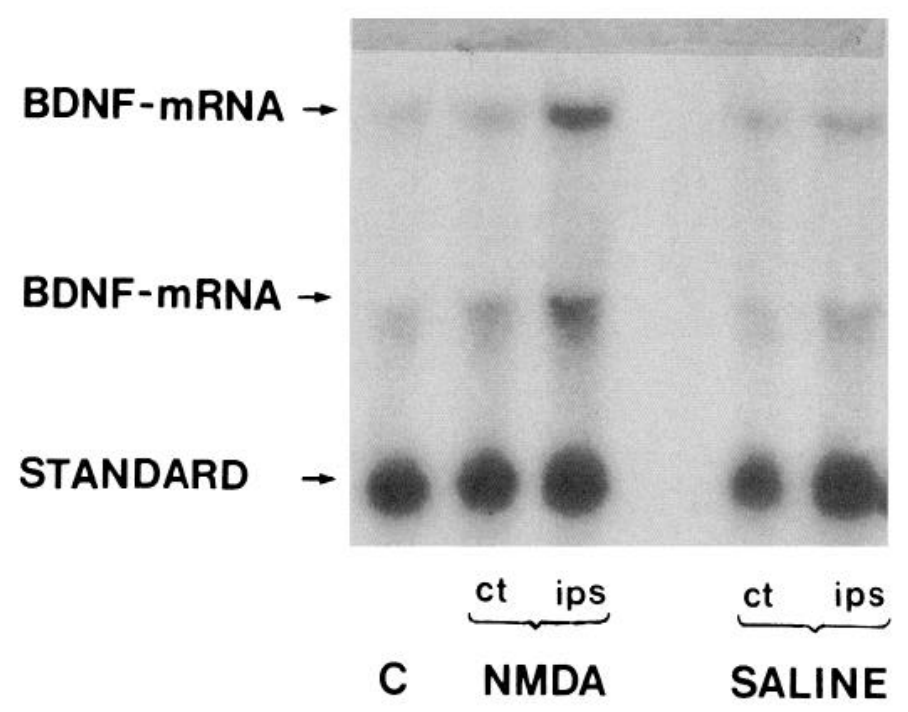

Figure 9. Effect of NMDA on BDNF mRNA levels in the hippocampus of P7 rats. Unilateral injections of $1.0 \mu \mathrm{l}$ of NMDA $(12 \mu \mathrm{g} / \mu \mathrm{l})$ into the lateral ventricle were performed under ether anesthesia as described in Materials and Methods. Control animals received either an equal volume of saline $(S A L I N E)$ or no treatment $(C)$. Three hours after NMDA or saline administration the animals were killed and RNA was extracted and analyzed, as indicated in Materials and Methods, in the ipsilateral (ips) and contralateral ( $c t$ ) hippocampus. administration, suggesting that NT-3 is regulated differently in the hippocampus during early postnatal development. As reported earlier (Maisonpierre et al., 1990a), NT-3 mRNA levels are high in the hippocampus of newborn rats and then steadily decline to the relatively low adult levels. Likewise, NT-3 mRNA levels in cultured hippocampal neurons were not influenced by depolarization induced by either high potassium concentrations or KA (data not shown).

A number of observations support the concept that the levels of BDNF and NGF mRNAs are controlled by neuronal activity. Depolarization of hippocampal neurons in vitro increases BDNF and NGF mRNA levels (Zafra et al., 1990; Lu et al., 1991) and KA mimics the effect of depolarization both in vitro and in vivo (Zafra et al., 1990). The basal expression of BDNF mRNA in vitro appears to be regulated by a balance between excitatory and inhibitory neurotransmitter systems (Zafra et al., 1991). Moreover, we have recently shown that the levels of BDNF mRNA in the visual cortex are regulated by visual input, demonstrating that neuronal activity regulates BDNF mRNA under physiological conditions (Castrén et al., 1992). The inability of $\mathrm{KA}$ to increase BDNF and NGF mRNA levels during the early postnatal development, as shown here and pointed out by Dugich-Djordjevic et al. (1992b), was taken to challenge the concept of activity-dependent regulation of neurotrophins. However, we demonstrate here that the activity-dependent regulation of BDNF and NGF mRNA levels during postnatal development is not 
mediated through $\mathrm{KA}$ receptors, but through the cholinergic system via NMDA receptors.

\section{References}

Alderson RF, Alterman AL, Barde YA, Lindsay RM (1990) Brainderived neurotrophic factor increases survival and differentiated functions of rat septal cholinergic neurons. Neuron 5:297-306.

Aronstan RS, Kellog C, Abood LG (1979) Development of muscarinic cholinergic receptors in inbred strains of mice: identification of receptor heterogeneity and relation to audiogenic seizure susceptibility. Brain Res 162:231-241.

Auburger G, Heumann R, Hellweg R, Korsching S, Thoenen H (1987) Developmental changes of nerve growth factor and its $\mathrm{mRNA}$ in the rat hippocampus: comparison with choline acetyltransferase. Dev Biol 120:322-328.

Ballarin M, Ernfors P, Lindfors N, Persson H (1991) Rapid induction of mRNA for brain derived neurotrophic factor after intrahippocampal injection of kainic acid. Exp Neurol 114:35-43.

Ben-Ari Y, Aniksztejn L, Bregestovski P (1992) Protein kinase C modulation of NMDA currents: an important link for LTP induction. Trends Neurosci 15:333-339.

Castrèn F, 7afra F, Thoenen H, I indholm D (1992) I ight regulates the expression of brain-derived neurotrophic factor in rat visual cortex. Proc Natl Acad Sci USA 19:9444-9448.

Cavalheiro EA, Silva D, Turski W, Calderazzo-Filho LS, Bortolotto ZA, Turski L (1987) The susceptibility of rats to pilocarpine-induced seizures is age-dependent. Dev Brain Res 37:43-58.

Chomczynski P, Sacchi N (1987) Single-step method of RNA isolation by acid guanidinium thiocyanate-phenol-chloroform extraction. Anal Biochem 162:156-159.

Dermott AB, Mayer ML, Westbrook GL, Smith SJ, Barker JL (1986) NMDA-receptor activation increases cytoplasmic calcium concentration in cultured spinal cord neurones. Nature 321:519-522.

DiStefano PS, Friedman B, Radziejewski C, Alexander C, Boland P, Schick CM, Lindsay RM, Wiegand SJ (1992) The neurotrophins BDNF, NT-3, and NGF display distinct patterns of retrograde axonal transport in peripheral and central neurons. Neuron 8:983-993.

Dugich-Djordjevic MM, Tocco G, Lapchar PA, Pasinetti GM, Najm I, Baudry M, Hefti F (1992a) Regionally specific and rapid increases in brain-derived neurotrophic factor messenger RNA in the adult rat brain following seizures induced by systemic administration of kainic acid. Neuroscience 47:303-315.

Dugich-Djordjevic MM, Tocco G, Willoughby DA, Najm I, Pasinetti G, Thompson RF, Baudry M, Lapchak PA, Hefti F (1992b) BDNF mRNA expression in the developing rat brain following kainic acid induced seizure activity. Neuron 8:1127-1138.

Ernfors P, Bengzon J, Persson H, Lindvall O (1991) Increased levels of messenger RNA for neurotrophic factors in the brain during kindling epileptogenesis. Neuron 7:165-176.

Freund TF, Antal M (1988) GABA-containing neurons in the septum control inhibitory interneurons in the hippocampus. Nature 336:170173.

Gall CM, Isackson PJ (1989) Limbic seizures increase neuronal production of messenger RNA for nerve growth factor. Science 245:758761

Gall CM, Murray K, Isackson PJ (1991) Kainic acid induced seizures stimulate increased expression of nerve growth factor mRNA in the rat hippocampus. Mol Brain Res 9:113-123.

Gärtner K (1991) Qualitätskriterien der Versuchstierforschung: Ergebnisse aus dem Sonderforschungbereich "Versuchstierforschung der Medizinischen und der Tierärztlichen Hochschule Hannover/DFG. Weinheim 1991.

Hartikka J, Hefti F (1988) Development of septal cholinergic neurons in culture: plating density and glial cells modulate effects of NGF on survival, fiber growth, and expression of transmitter-specific enzymes. J Neurosci 8:2967-2985.

Hatanaka H, Tsukui H, Nihonmatsu I (1988) Developmental change in the nerve growth factor action from induction of choline acetyltransferase to promotion of cell survival in cultured basal forebrain cholinergic neurons from postnatal rats. Dev Brain Res 39:85-95.

Hefti F (1986) Nerve growth factor promotes survival of septal cholinergic neurons after fimbrial transections. J Neurosci 6:2155-2162.

Hefti F, Hartikka J, Eckenstein H, Gnahn H, Heumann R, Schwab M (1985) Nerve growth factor (NGF) increases choline acetyltransferase but not survival or fiber outgrowth of cultured fetal septal cholinergic neurons. Neuroscience 14:55-68.

Hohn A, Leibrock J, Bailey K, Barde YA (1990) Identification and characterization of a novel member of the nerve growth factor/brain derived neurotrophic factor family. Nature 344:339-341.

Holmes GL, Thompson JL (1988) Effects of kainic acid on seizure susceptibility in the developing brain. Dev Brain Res 39:51-59.

Insel TR, Miller LP, Gelhard RE (1990) The ontogeny of excitatory amino acid receptors in the rat forebrain-I. $N$-methyl-D-aspartate and quisqualate receptors. Neuroscience 35:31-43.

Isackson PJ, Huntsman MM, Murray KD, Gall CM (1991) BDNF mRNA expression is increased in adult forebrain after limbic seizures: temporal patterns of induction distinct from NGF. Neuron 6:937948.

Kaisho Y, Yoshimura K, Nakahama K (1990) Cloning and expression of a cDNA encoding a novel human neurotrophic factor. FEBS Lett 266:187-191.

Knüsel B, Winslow JW, Rosenthal A, Burton LE, Seid DP, Nikolics K, Hefti F (1991) Promotion of central cholinergic and dopaminergic neuron differentiation by brain-derived neurotrophic factor but not ncurotrophin-3. Proc Natl Acad Sci USA 88:961-965.

Koh S, Loy R (1989) Localization and development of nerve growth factor-sensitive rat basal forebrain neurons and their afferent projections to hippocampus and neocortex. J Neurosci 9:2999-3018.

Lindefors N, Ernfors P, Falkenberg T, Persson H (1992) Septal cholinergic afferents regulate expression of brain-derived neurotrophic factor and beta-nerve growth factor mRNA in rat hippocampus. Exp Brain Res 88:78-90.

Lindholm D, Heumann R, Hengerer B, Thoenen $H$ (1988) Interleukin 1 increases stability and transcription of mRNA encoding nerve growth factor in cultured rat fibroblasts. J Biol Chem 263:16348-16351.

Lu B, Yokoyama M, Dreyfus CF, Black IB (1991) Depolarizing stimuli regulate nerve growth factor gene expression in cultured hippocampal neurons. Neurobiology 88:6289-6292.

Maisonpierre PC, Belluscio L, Friedman B, Alderson R, Wiegand SJ, Furth ME, Lindsay RM, Yancopoulos GD (1990a) NT3, BDNF, and NGF in the developing rat nervous system: parallel as well as reciprocal patterns of expression. Neuron 5:501-507.

Maisonpierre PC, Belluscio L, Squinto S, Nancy YI, Furth ME, Lindsay RM, Yancopoulos GD (1990b) Neurotrophin-3: a neurotrophic factor related to NGF and BDNF. Science 247:1446-1451.

Markram H, Segal M (1992) The inositol 1,4,5-trisphosphate pathway mediates cholinergic potentiation of rat hippocampal neuronal responses to NMDA. J Physiol (Lond) 447:513-533.

Millan MH, Chapman AG, Meldrum BS (1991) Stimulation of hippocampal glutamate and aspartate released by focally applied pilocarpine: in vivo dialysis study. Abstracts of the 14th Annual Meeting of the European Neuroscience Association 3113:181.

Milner TA, Loy R, Amaral DG (1983) An anatomical study of development of the septohippocampal projections in the rat. Dev Brain Res 8:343-371.

Monaghan DT, Holets VR, Toy DW, Cotman CW (1983) Anatomical distribution of four pharmacologically distinct ${ }^{3} \mathrm{H}$-L-glutamate binding sites. Nature 306:176-178.

Paxinos O, Törk I, Tecott LH, Valentino K (1991) Atlas of the developing rat brain. San Diego: Academic.

Regher WG, Tank DW (1990) Postsynaptic NMDA receptor mediated calcium accumulation in hippocampal CA1 pyramidal cell dendrites. Nature 345:807-810.

Rosenthal A, Goeddel DV, Nguyen T, Lewis M, Shih A, Laramee GR, Nikolics K, Winslow JW (1990) Primary structure and biological activity of a novel human neurotrophic factor. Neuron 4:767-773.

Schnürch H, Risau W (1991) Differentiating and mature neurons express the acidic fibroblast growth factor gene during chick neural development. Development 111:1143-1154.

Schwab ME, Otten U, Agid Y, Thoenen H (1979) Nerve growth factor (NGF) in the rat CNS: absence of specific retrograde axonal transport and tyrosine hydroxylase induction in locus coeruleus and substantia nigra. Brain Res 168:473-483.

Seiler M, Schwab ME (1984) Specific retrograde transport of nerve growth factor (NGF) from neocortex to nucleus basalis in the rat. Brain Res 300:33-39.

Turski WA, Cavalheiro EA, Schwarz M, Czuczwar SJ, Kleinrok Z, Turski L (1983) Limbic seizures produced by pilocarpine in rats: a 
behavioral, electroencephalographic and neuropathological study. Behav Brain Res 9:315-336.

Turski WA, Cavalheiro EA, Bortolotto ZA, Moraes Mello LEA, Schwartz M, Turski L (1984) Seizures produced by pilocarpine in mice: behavioral, electroencephalographic and morphological analysis. Brain Res 321:237-253.

van Chaldorp KJ, de Jonge A, Thoolen MJM, Zwieten PA (1985) Subclassification of muscarinic receptor in heart, urinary bladder and sympathetic ganglia in the pithed selectivity of some classical agonists. Naunyn Schmiedebergs Arch Pharmacol 331:301-306.

Zafra F, Hengerer B, Leibrock J, Thoenen H, Lindholm D (1990) Activity dependent regulation of BDNF and NGF mRNAs in the rat hippocampus is mediated by non-NMDA glutamate receptors. EMBO J 9:3545-3550.

Zafra F, Castrén E, Thoenen H, Lindholm D (1991) Interplay between glutamate and gamma-aminobutyric acid transmitter systems in the physiological regulation of brain-derived neurotrophic factor and nerve growth factor synthesis in hippocampal neurons. Proc Natl Acad Sci USA 88:10037-10041.

Zafra F, Lindholm D, Castrén E, Hartikka J, Thoenen H (1992) Regulation of brain-derived neurotrophic factor and nerve growth factor mRNA in primary cultures of hippocampal neurons and astrocytes. J Neurosci 12:4793-4799. 